DOI:

UDC 631.312.021.4:631.312.001.1

S.S. Tishchenko, Doctor of Technical Sciences, Professor, Environmental Mathematics Department, voloskrs@i.ua

Dnipro State University of Agriculture and Economics, Dnipro

\title{
MODELING OF EXPANDING SURFACES, WHICH INCIDENT BY TWO DIRECT DRIVE CURVESS
}

The geometric model of the expanding surface which is incident to two direction curves is considered. On the basis of the developed model, the conditions for the existence of the surface are derived, which makes it possible to apply the developed model to the design of machine-building products, in particular those working in a dense environment.

Keywords: geometry; surface; expansion surfaces; model; working bodies.

Розглянуто геометричну модель розгортної поверхні яка інцидентна двом напрямним кривим. На основі розробленої моделі виведено умови існування поверхні, щзо дає змогу застосувати розроблену модель при проектуванні мачинобудівних виробів, зокрема таких, щэо працюють у щільному середовищі.

Ключові слова: геометрія; поверхні; розгортні поверхні; модель; робочі органи.

\section{Formulation of the problem}

For multi-nomenclature machine-building production the most important of the technological equipment is machining, the optimum service life does not exceed for 7 years. This equipment includes working bodies that work in dense environments: these are excavator buckets, bulldozer shelves, general-purpose and special-purpose plows, and many others that work in soil. At the heart of such working bodies is a surface that can be quite complex. An analysis of the working methods of working bodies shows that in the early stages of design it is very difficult to assess and take into account the variety of factors that affect the quality of its work. Therefore, there is a problem of choosing the design and technological parameters of the surfaces, in order to ensure the technological purpose of the working body. At the same time, there is no scientific and methodological base, including generalized surface models, which allows taking into account the design and technological features of the working bodies that are being designed. Thus, the development of surface models that allow the design of working bodies to work in a dense environment is a broad spectrum solution to an important problem.

\section{Analysis of recent research and publications}

One of the main directions of applied geometry development is the design of surfaces that meet different positional, metric, and differential conditions. At present, in these areas, certain results are obtained, which stand at the level of modern requirements, design engineering. In $[1,8]$, geometric models of ruler surfaces with multivariable sets of lines and special surface lines are presented, but a large number of parameters and difficult definition of special lines, for example, curvature lines complicate the design of working bodies. In $[9,10,11]$ geometrical models of surfaces of soil tillage working bodies, in particular plows of agricultural purpose are considered. The disadvantage of these models is to specify them for a specific working body, and the application of the model for another working body is much more difficult. This leads to the fact that in the design of the working body in each case, you need to develop your algorithm for surface formation.

The main directions of development of analytical design of surfaces are formulated by II Kotov [2, 3] and consist in the development of methods of constructing lined surfaces, their continuous frames with observance of given differential-isometric conditions. Strengthening requirements for precision characteristics, increasing the speed and the need to improve the dynamic characteristics of the interaction of surfaces with a dense environment further complicate the required geometry of the surfaces. For example, for operated surfaces in dense environments or at high speeds. 
The above causes the urgent need to develop new methods for obtaining mathematical models of surfaces that meet a large number of differential-geometric conditions with a given degree of accuracy. The energy costs thus depend on the geometric properties of the surfaces.

The use of working bodies with expandable surfaces is widespread in technology. This position is provided by the differential-parametric properties of the unfolding surfaces:

- the tangent plane touches the surface along the whole rectilinear formation and does not change its position in space when the point of contact changes;

- normal to the surface when moving the point of contact along the formation does not change its position.

Working bodies with unfolding surfaces have the advantage over non-expandable ones, first of all, because at the unfolding surface, the working body is made by a simple bend that eliminates plastic deformations, which leads to a violation of the shape of the surface. Secondly, if the working body is working in a dense environment, it has less traction resistance, because on the unfolding surface the dense medium will move more orderly because at each instant of time the unfolding surface is a plane.

Particularly noteworthy is that working bodies with expandable surfaces have linear wear due to their properties.

The greatest contribution to the theory of unfolding surfaces was made by V. M. Naidysh [5, 6]. Based on the differential properties of the unfolding surfaces, he developed a number of algorithms for their design. In [7] adaptation of tillage working bodies to certain conditions is given

These algorithms are generic in nature, so detailing them to save significant material and energy costs when designing and manufacturing working bodies is an important task.

\section{Formulation of the purpose of the study}

The purpose of the work is to provide rational choice of the parameters of the model of the unfolding surface when designing process equipment using automated systems.

The object of research is the design of surfaces of working bodies of machining and technological equipment, and working bodies of machines operating in conditions of dense environments, and made of structural materials of general mechanical engineering purpose.

The paper deals with the geometric model of a linear unfolding surface, the conditions of existence of such a surface, and presents a generalized algorithm for constructing a surface, regardless of the type of working body or engineering product.

\section{Presenting main material}

To develop a surface model, we define a Cartesian coordinate system Oxyz . In this system we define two curves:

$$
\begin{aligned}
& m: x=x_{1}(u), y=y_{1}(u), z=z_{1}(u), \\
& n: x=x_{2}(v), y=y_{2}(v), z=z_{2}(v),
\end{aligned}
$$

where $u$ and $v$ - parameters.

These curves distinguish from the set of direct congruences

$$
y=a x+b, \quad z=c x+d .
$$

In this case, the position parameters $\mathrm{a}, b, c, d$ depend on $\mathrm{u}$ and $\mathrm{v}$ and are determined from the system of equations (1), (2), (3), so that

$$
\begin{aligned}
& a=\frac{y_{1}-y_{2}}{x_{1}-x_{2}} ; \quad b=y_{1}-a x_{1} ; \\
& c=\frac{z_{1}-z_{2}}{x_{1}-x_{2}} ; \quad d=z_{1}-c x_{1} .
\end{aligned}
$$

To remove the expanding torso surface, we introduce an additional condition in the form of compatibility, equations defining the equipment of both curves by the norms of the future surface,

$$
\left\{\begin{array}{l}
z_{1}^{\prime}=p \cdot x_{1}^{\prime}+q \cdot y_{1}^{\prime} \\
z_{2}^{\prime}=p \cdot x_{2}^{\prime}+q \cdot y_{2}^{\prime}
\end{array}\right.
$$


where the strokes denote the derivatives of the functions that set the curves by their parameter and the differential equation of the linear surface

$$
p+a q-c=0
$$

which is equivalent to the equation

$$
\left|\begin{array}{ccc}
x_{1}^{\prime} & y_{1}^{\prime} & z_{1}^{\prime} \\
x_{2}^{\prime} & y_{2}^{\prime} & z_{2}^{\prime} \\
x_{1}-x_{2} & y_{1}-y_{2} & z_{1}-z_{2}
\end{array}\right|=0 .
$$

Equation (6) expresses the fact that the surface normal at the corresponding points of the given curves (which belong to one straight line) are parallel, which is equivalent to having a common tangent plane to the surface at the indicated points. Indeed, given (4) and (5), equation (8) takes the form

$$
\left|\begin{array}{ccc}
x_{1}^{\prime} & y_{1}^{\prime} & z_{1}^{\prime} \\
x_{2}^{\prime} & y_{2}^{\prime} & z_{2}^{\prime} \\
x-x_{2} & y-y_{2} & z-z_{2}
\end{array}\right|=0
$$

that is, the vectors tangent to the curves and the generic coplanar.

Equation (8) allows us to determine the dependence between the parameters $\mathrm{u}$ and $\mathrm{v}$ on the surface unfolding condition

$$
\varphi(u, v)=0,
$$

which together with (3), (4), (5) gives the equation of the search surface.

If one of the parameters (such as u) can be explicitly expressed in (9) through the second parameter,

$$
u=\varphi_{1}(v)
$$

then, given (4), (5) and (10), the surface equation will look like

$$
y=a(v) \cdot x+b(v), z=c(v) \cdot x+d(v) .
$$

To find the edge of $l$, we differentiate (11) by $v$

$$
x=\frac{b^{\prime}(v)}{a^{\prime}(v)}=-\frac{d^{\prime}(v)}{c^{\prime}(v)} .
$$

One of equations (12) in conjunction with (11) defines $l$.

Obviously, not every two lines in their shape and position in space will allow for a torso surface. In solving the determinant (9), the following cases can occur (except for the one discussed above, which leads to (9)):

- the determinant is equal to zero (the curves are in the same plane, which is the desired surface regardless of the function $\varphi$ );

- as a result of decoupling (8) it becomes an equation from one parameter (there is no torso surface, there are separate generators whose number is equal to the number of roots of equations where there is a common tangent plane to the given curves);

- the determinant (8) is not zero (the torso surface does not exist).

Thus, the desired result is only the case leading to (9).

Consider equations (6) and (8). The minors $2 \times 2$ of the first two lines of the determinant (8) are the coordinates of the surface normal $\vec{n}\{\Delta x, \Delta y, \Delta z\}$, so

where

$$
p=\frac{-\Delta x}{\Delta z}, q=\frac{-\Delta y}{\Delta z},
$$

$$
\Delta x=-\left|\begin{array}{ll}
y_{1}^{\prime} & z_{1}^{\prime} \\
y_{2}^{\prime} & z_{2}^{\prime}
\end{array}\right| ; \Delta y=\left|\begin{array}{ll}
x_{1}^{\prime} & z_{1}^{\prime} \\
x_{2}^{\prime} & z_{2}^{\prime}
\end{array}\right| ; \Delta z=\left|\begin{array}{ll}
x_{1}^{\prime} & y_{1}^{\prime} \\
x_{2}^{\prime} & y_{2}^{\prime}
\end{array}\right| .
$$


Surface design is greatly simplified if the guide curves are level lines. For example, if $m$ and $n$ are horizontal, then the condition of surface unfolding is $\Delta z=0$, and for the fronts $\Delta y=0$, etc.

Equation (7) allows one of the functions, for example, (2), to be defined to satisfy the existence of a spreading surface. In this case, the functions $x_{1}, y_{1}, z_{1}$ and $x_{2}, y_{2}$, and, must be known.

Write equation (8) as follows

$$
A\left|\begin{array}{ll}
y_{1}^{\prime} & z_{1}^{\prime} \\
y_{2}^{\prime} & z_{2}^{\prime}
\end{array}\right|-B\left|\begin{array}{ll}
x_{1}^{\prime} & z_{1}^{\prime} \\
x_{2}^{\prime} & z_{2}^{\prime}
\end{array}\right|+\left(z_{1}-z_{2}\right) \cdot C=0
$$

where $A=x_{1}-x_{2}, B=y_{1}-y_{2}, C=\left|\begin{array}{ll}x_{1}^{\prime} & y_{1}^{\prime} \\ x_{2}^{\prime} & y_{2}^{\prime}\end{array}\right|$. function

From the obtained expression we arrive at a differential equation of a relatively unknown

$$
z_{2}^{\prime}-\frac{C}{F} z_{2}=0
$$

where $F=\left(A \cdot y_{1}^{\prime}-B \cdot x_{1}^{\prime}\right)-A \cdot y_{2}^{\prime} \cdot z_{1}^{\prime}-B \cdot z_{1}^{\prime} \cdot x_{2}^{\prime}+C \cdot z_{1}^{\prime}$.

Surface construction algorithm

1. We select the curves $m$ and $n$ (equations (1) and (2)) according to the technological process. For example, for the design of a general-purpose plow shelf, these can be trajectories of the chuck motion.

2. Find the generators $x_{1}^{\prime}, y_{1}^{\prime}, z_{1}^{\prime}, x_{2}^{\prime}, y_{2}^{\prime}, z_{2}^{\prime}$.

3. We construct the determinant (8) as a result of the solution which we find (9). If dependence (9) on the determinant (8) does not follow, then there is no solution.

4. We determine the coefficients $a, b, c, d$ according to (4) and (5).

5. Find $a, b, c, d$ with (9).

6. Write the equation of the surface (3) which will be given by the set of rectilinear generators.

According to the specified model, a semi-screw general-purpose plow shelf is constructed in which the formation in each position will be determined by two angles of inclination to the projection planes.

The coordinate system $O x y z$ is chosen such that the axis $O x$ is directed opposite to the movement of the plow body, the axis $O y$ is located in the horizontal plane and the axis is vertical. With this arrangement of the surface, the angle of projection of the genera on the horizontal plane of projections $O x y$ is denoted by $\gamma$ the angle of projection of the genera to the axis $O x$ on the vertically longitudinal plane through $\beta$. Surface diagram and function graphs $a(x)=\operatorname{tg} \gamma(x)$ та $b(x)=\operatorname{tg} \beta(x)$ are presented in Fig. 1. Logarithmic spirals were adopted as the guide curves

$$
r_{1}=r_{01} e^{w_{1} \varphi_{1}} \text { end } r_{2}=r_{02} e^{w_{2} \varphi_{2}}
$$

where $r_{1}, r_{2}$ - the current radius vectors of the guide curves; $r_{01}, r_{02}-$ the initial radius vectors of the guide curves (1), (2); $w_{1}, w_{2}$ - tangents of angles between the current radius vector and the tangent; $\varphi$ parameter, namely the polar angle of rotation of the radius of the vector. The coordinate is programmed in the radians of the polar angle $\varphi_{1}$.

Agro-technical assessment of the quality of work of plows with standard cultural and semiscrew shelves of buildings was carried out on the percentage of plowing of crop residues. Taking into account the working speed of the plows of $2.7 \mathrm{~m} / \mathrm{s}$, the percentage of plowing of crop residues for the plow with the half-screw shelves was $97.9 \%$, and with the crop - $78.1 \%$, which is higher on $19.8 \%$. Experimental studies have shown the prospect of using semi-screw shelves on general-purpose shelf plows. 


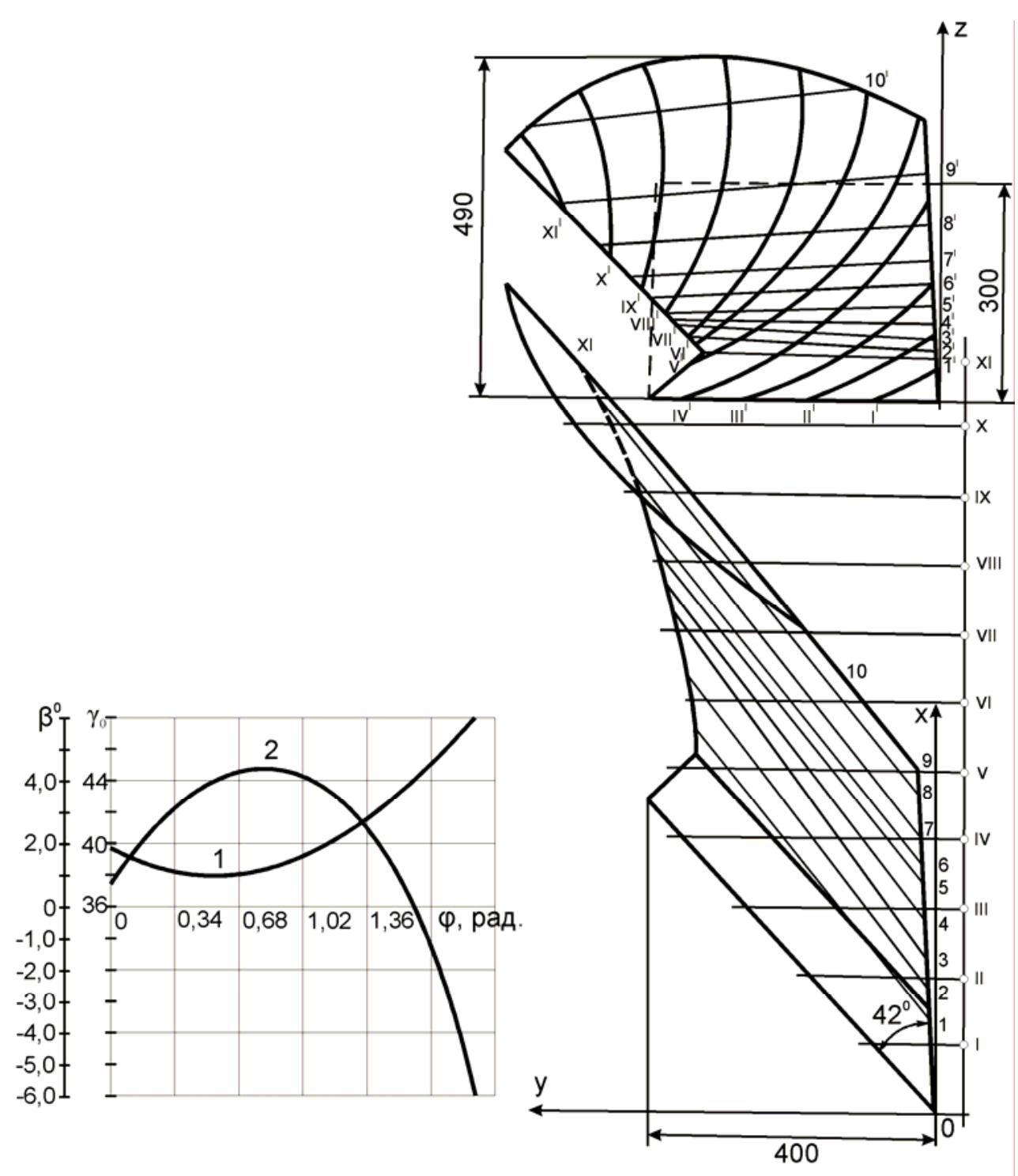

Fig. 1. The scheme of the surface of the plow body and the slope function of the projection of the genera: 1 - graph of the function $a(\varphi) ; 2$ - function graph $b(\varphi)$

\section{Conclusions and prospects for further research}

The model of the unfolding surface, which is incident to the two guide curves, has been successfully applied in the design of the working surface of a general-purpose plow. Experimental studies have shown the advantage of expandable surfaces as working shelves for general-purpose plows. Thus, the geometric surface model is promising and can be used in the design of other shelves working bodies. Further studies should aim to determine the surface curvature to be taken into account in computer design.

\section{References}

[1] Golovanov, N.N. (2002). Geometricheskoe modelirovanie: nauchnoe . izdanie [Geometrical design: scientific publication] Moscow: Publishing house of physical and mathematical literature [in Russia]

[2] Kotov, I.I. (1975) Metodicheskoe posobie po nachertatelnoy geometrii "Algoritmy konstruirovaniya karkasnykh poverkhnostey" [Methodical manual on descriptive geometry "Algorithms of constructing of framework surfaces"]. Moscow: Publishing House Mosk. Aviation in-that [in Russia] 
[3] Kotov, I.I. (1973). Nachertatelnaya geometriya. Kurs lektsiy dlya slushateley FPK [Descriptive geometry. A course of lectures for students of FPK]. Moscow: Publishing House Mosk. Aviation in-that [in Russia]

[4] Malyy, A. D., \& Popudnyak Yu. Ya., \&. Ulchenko T. V., Starosolskaya T. V. (2014). Kvazilineynye graficheskie modeli prostranstva [Quasilinear graphical space mode]. Mosty ta tuneli: teoriya, doslidzhennya, praktika - Bridges and tunnels: theory, research, practice, 5, 51-56 [in Ukraine]

[5] Naydysh V.M. (1980). Konstruirovanie poverkhnostey iz mnogoparametricheskikh mnozhestv liniy i poverkhnostey [Designing surfaces from multiparameter sets of lines and surfaces] Nauchnye trudy Ukrainskoy selskokhozyaystvennoy akademii - Scientific works of the Ukrainian Agricultural Academy, 234, 141-144 [in Ukraine]

[6] Naydysh V.M. (1981)Konstruirovanie poverkhnostey, prokhodyashchikh cherez ikh spetsialnye linii [Construction of surfaces passing through their special lines] Izvestie vysshikh uchebnykh zavedeniy: aviatsionnaya tekhnika - Izvesestie of higher educational institutions: aviation engineering, 2, 88-90 [in Russia]

[7] Naydysh V.M. (1979) Razvertyvayushchiesya lineichatye poverhnosti zadannye liniei proctranstva parametrov [Expanding ruled surfaces defined by a parameter space line] Prikladnaia geometriia i inzhenernaia grafika - Applied Geometry and Engineering Graphics, 27, 89-90 [in Ukraine]

[8] Tishchenko S.S. (2007) Geometricheskaya adaptatsiya poverkhnostey pochvoobrabatyvayushchikh rabochikh organov $\mathrm{k}$ vypolnyaemomu protsessu [Geometric adaptation of the surfaces of tillage workers to the process being performed] Visnyk Kharkivskogo nacionalnogo tekhnichnogo universytety im p. vasylenka - Вісник Харківського national technical service to the university of the state government im. P. Vasilenka, 59, 110-114 [in Ukraine]

[9] Tishchenko S.S. (2005) Geometricheskaya model adaptivnoy poverkhnosti pochvoobrabatyvayushchego rabochego organa intsidentnoy dvum krivym [Geometric model of the adaptive surface of a soil-cultivating working body incident to two curves] Sbornik nauchnyh rabot Krymskogo gosudarstvennogo universiteta - Collection of scientific works of the Crimean State University, 84, 242-247 [in Ukraine]

[10] Tishchenko S.S., \& Karas V.V. (2006) Konstruirovanie poverkhnosti okuchnika dlya propashnykh kultur po absolyutnym traektoriyam dvizheniya pochvy [Designing the surface of the hoop for row crops on absolute paths of soil movement] Visnyk Dnipropetrovskogo derzhavnogo agrouniversytety - Bulletin Dnipropetrovsk sovereign agroneurs, 1, 27-30 [in Ukraine]

[11] Trukhina V.D. (1989) Primenenie vychislitelnoy tekhniki pri proektirovanii lemeshno-otvalnykh poverkhnostey [The use of computing in the design of plow-bottom surfaces]. Barnaul [in Russia].

[12] Lawrence D. Brown. A semiparametric multivariate partially linear model: A difference approach / Lawrence D. Brown, Michael Levine,Lie Wang // Journal of Statistical Planning and Inference. - 2016. - Vol. 178. - P. 99-111. doi:10.1016/j.jspi.2016.06.005

\section{МОДЕЛЮВАННЯ РОЗГОРТНИХ ПОВЕРХОНЬ, ІНЦИДЕНТНИХ ДВОМ НАПРЯМНИМ КРИВИМ Тищенко С.С.}

\section{Реферат}

Для забезпечення раціонального вибору параметрів поверхонь деталей при проектуванні технологічного обладнання потрібно базуватися на методах штучного інтелекту, зокрема на узагальнених алгоритмах. У статті розглянуто геометричну модель лінійчатої розгортної поверхні, та умови іiї поверхні. Надається узагальнений алгоритм побудови розгортної поверхні незалежно від типу робочого органу чи виробів машинобудування. Однією з найпоширеніших у галузі поверхонь $є$ розгортні поверхні, які займають особливе положення, завдяки своїм дифе- 
ренціально-параметричним властивостям: дотична площина торкається поверхні вздовж прямолінійної твірної і не змінює свого положення в просторі при зміні точки контакту. Такі поверхні можуть бути виготовлені згинанням листового металу. Ці положення дозволяють виготовити продукцію, заощаджуючи значні матеріальні та енергетичні засоби; тому розробка геометричних моделей таких поверхонь $є$ важливим завданням. Наведена геометрична модель розгортної поверхні, напівгвинтового корпусу плугу загального призначення.

Експериментальні дослідження показали перспективність застосування напівгвинтових полиць плугах, особливо в двоярусній оранці. Враховуючи робочу швидкість руху плуга 2,7 / / $c$, відсоток залишків сільськогосподарських культур на оранці з напівгвинтовими полицями становить 97,9\%, а з культурними корпусами плугів - 78,1\%.

Розроблені підходи до вирішення проблеми розпізнавання умов існування розгортних поверхонь при застосуванні програми по їі концептуальній моделі. Побудовано відповідні процедури обчислювальних алгоритмів. Математична модель, що визначає вплив параметрів поверхонь на їх експлуатаційні властивості - силу опору. Теоретичні основи цієї моделі можуть бути використані у середовищі програмування для будь-якого інтерфейсу. В даний час ця модель може дати значні результати, які відповідають сучасним вимогам будівельної інженерії. У процесі параметричної оптимізації модель генерує безліч бажаних значень параметрів поверхонь. Модель дозволяє зображення розгортних поверхонь за формальними ознаками. Результатом $\epsilon$ спряження розгортних поверхонь до певної групи, кожна з яких відповідає безлічі окремих параметрів обчислювальної моделі.

\section{Література}

1. Голованов Н. Н. Геометрическое моделирование : науч. изд. Москва : Изд-во физикоматематической литературы, 2002. 472 с.

2. Котов И. И. Методическое пособие по начертательной геометрии "Алгоритмы конструирования каркасных поверхностей" . Москва : Изд-во Моск. авиац. ин-та, 1975. 63 с.

3. Котов И. И. Начертательная геометрия. Курс лекций для слушателей ФПК. Москва : Изд. Моск. авиац. ин-та, 1973. 198 с.

4. Квазилинейные графические модели пространства / А. Д. Малый, О. Ю. Попудняк, Т. В. Ульченко, Т. В. Старосольська. Мости та тунелі : теорія, дослідження, практика. 2014. № 5. C. 51-56.

5. Найдыш В. М. Конструирование поверхностей из многопараметрических множеств линий и поверхностей . Научные труды Украинской сельскохозяйственной академии. 1980. № 234. C. $141-144$.

6. Найдыш В. М. Конструирование поверхностей, проходящих через их специальные линии. Известие высших учебных заведений: авиачионная техника. 1981. № 234. С. 88-90.

7. Найдыш В. М. И. Г. Балюба. Развертывающиеся линейчатые поверхности, заданные линией пространства параметров. Прикладная геометрия и инженерная графика. 1979. № 27. С. 89-90.

8. Тищенко С. С. Геометрическая адаптация поверхностей почвообрабатывающих рабочих органов к выполняемому процессу. Вісник Харківського національного технічного університету сільського господарства ім. П. Василенка. 2007. № 59. С. 110-114.

9. Тищенко С. С. Геометрическая модель адаптивной поверхности почвообрабатывающего рабочего органа инцидентной двум кривым. Сборник научных работ Крымского государственного университета. 2005. № 84. С. 242-247.

10. Тищенко С. С., В. В. Карась. Конструирование поверхности окучника для пропашных культур по абсолютным траекториям движения почвы. Вісник Дніпропетровського державного агроуніверситету. 2006. № 1. С. 27-30.

11. Трухина В. Д. Применение вычислительной техники при проектировании лемешноотвальных поверхностей. Барнаул, 1989. 82 с.

12. Lawrence D. Brown. A semiparametric multivariate partially linear model: A difference approach / Lawrence D. Brown, Michael Levine,Lie Wang // Journal of Statistical Planning and Inference.2016.- Vol. 178. - P. 99-111. doi:10.1016/j.jspi.2016.06.005 